\title{
Significant antitumor activity of cationic multilamellar liposomes containing human interferon- $乃$ gene in combination with 5-fluorouracil against human renal cell carcinoma
}

\author{
KOSUKE YAMAMOTO ${ }^{1}$, YOICHI MIZUTANI ${ }^{1}$, HIROYUKI NAKANISHI ${ }^{1}$, JUN FUJIWARA ${ }^{1}$, \\ HIROKAZU ISHIDA ${ }^{1}$, DAISUKE TOIYAMA ${ }^{1}$, KOICHI ABE ${ }^{1}$, ISSEI HAYASHI ${ }^{1}$, KOICHI OKADA ${ }^{1}$, \\ AKIHIRO KAWAUCHI ${ }^{1}$, MASAAKI MIZUNO ${ }^{2}$, JUN YOSHIDA ${ }^{2}$ and TSUNEHARU MIKI ${ }^{1}$ \\ ${ }^{1}$ Department of Urology, Kyoto Prefectural University of Medicine, Kyoto 602-8566; ${ }^{2}$ Department of \\ Neurosurgery, Nagoya University, Postgraduate School of Medicine, Nagoya 466-8550, Japan
}

Received April 7, 2008; Accepted June 2, 2008

DOI: 10.3892/ijo_00000041

\begin{abstract}
Immunotherapy is one of the most effective treatments against metastatic renal cell carcinoma (RCC). However, the response rate is not high. Therefore, more effective therapies are necessary for patients with metastatic RCC. We previously reported on the significant antitumor activity of cationic multilamellar liposome containing human interferon- $\beta$ (huIFN- $\beta$ ) gene (IAB-1) against RCC. We then examined the antitumor effect of IAB-1 in combination with anticancer drugs against RCC. The cytotoxicity of IAB-1 alone, and in combination with anticancer drugs, cisplatin, adriamycin, 5-fluorouracil, gemcitabine, paclitaxel and irinotecan hydrochloride against the human RCC cell line NC65 was examined by the colorimetric method using tetrazolium salt. For the in vivo study, we used NC65 cells inoculated into the severe combined immunodeficiency mouse. The results showed that the in vitro combination therapy with IAB-1 and 5-FU was more cytotoxic than IAB-1 alone. However, synergistic cytotoxicity was not observed when combined with IAB-1 and other anticancer drugs. NC65 tumors transfected with IAB-1 in mice were smaller than those
\end{abstract}

Correspondence to: Dr Yoichi Mizutani, Department of Urology, Kyoto Prefectural University of Medicine, Kawaramachi-Hirokoji, Kamigyo-ku, Kyoto 602-8566, Japan

E-mail: ymizutan@koto.kpu-m.ac.jp

Abbreviations: ADR, adriamycin; CDDP, cisplatin; CPT-11, irinotecan hydrochloride; DPD, dihydropyrimidine dehydrogenase; E.L., empty liposome; 5-FU, 5-fluorouracil; GEM, gemcitabine; IAB-1, cationic multilamellar liposome containing human interferon- $\beta$ gene; IFN, interferon; OPRT, orotate phosphoribosyltransferase; PBS, phosphate-buffered saline; PTX, paclitaxel; RCC, renal cell carcinoma; SCID, severe combined immunodeficiency; $\mathrm{TP}$, thymidine phosphorylase; TS, thymidylate synthase

Key words: cationic multilamellar liposome containing human interferon- $\beta$ gene, 5 -fluorouracil, gene therapy, renal cell carcinoma receiving an injection of empty liposome or the recombinant huIFN- $\beta$ protein. Treatment with IAB- 1 in combination with 5 -FU resulted in significant anticancer activity. IAB-1 enhanced the activity of thymidine phosphorylase (TP), which converts 5-FU to the active metabolite, FdUMP. In contrast, IAB-1 decreased the activity of thymidylate synthase (TS), which is a target enzyme of 5-FU. In conclusion, these findings indicate that a combination of IAB-1 and 5-FU may have enhanced antitumor activity against human RCC, suggesting its potential clinical application. The mechanism of enhanced cytotoxicity by combination therapy with IAB-1 and 5-FU may up-regulate TP activity and down-regulate TS activity.

\section{Introduction}

Metastatic renal cell carcinoma (RCC) is resistant to conventional chemotherapy and radiotherapy. Immunotherapy including interferon (IFN) and interleukin 2 (IL-2) is a relatively effective treatment against metastatic RCC. However, the response rate is $\sim 15 \%$.

Many investigators have attempted to enhance the effectiveness of IFNs by combining them with other biological agents, but the effects were inadequate (1-5). Gene therapy trials using cytokine genes such as granulocyte macrophagecolony stimulating factor $(6,7)$ or IL-2 $(8,9)$ have commenced in patients with metastatic RCC. Although these therapies appear to be safe, their efficacy has yet to be proven. Therefore, the development of novel strategies for metastatic RCC is desirable.

The RCC cells treated with cationic multilamellar liposome containing human interferon- $\beta$ gene (IAB-1) constantly secreted significant amounts of human interferon- $\beta$ (huIFN- $\beta$ ) protein (10). Apoptosis was observed in cells treated with IAB-1, but the recombinant huIFN- $\beta$ protein failed to induce apoptosis. NC65 tumors (human RCC cell line) (11) transfected with IAB-1 in mice were significantly smaller than those receiving an injection of empty liposome or recombinant huIFN- $\beta$ protein. To find a more effective therapy against metastatic RCC, we examined the antitumor effect of IAB-1 in combination with anticancer drugs against RCC. 


\section{Materials and methods}

Cell line. The NC65 human RCC cell line was maintained in RPMI-1640 medium (Life Technologies Inc., Gaithersburg, MD) supplemented with $100 \mathrm{U} / \mathrm{ml}$ penicillin, $100 \mu \mathrm{g} / \mathrm{ml}$ streptomycin (Life Technologies Inc.) and 10\% fetal bovine serum (Life Technologies Inc., Bio-cult, Glasgow, Scotland, UK).

Reagents. IAB-1 is a plasmid DNA/lipid complex composed of plasmid (pSV2IFNß) that contains the SV40 early promoter, the huIFN- $\beta$ coding sequence (12), and positively charged liposomes [N-( $\alpha$-trimethyl ammonioacetyl)-didodecyl-Dglutamine chloride, dilauroyl phosphatidyl-choline, and dioleoyl phosphatidylethanolamine at a molar ratio of 1:2:2] (13-17). The IAB-1 was dissolved in phosphate-buffered saline (PBS) at a final concentration of $50 \mathrm{nmol}$ of lipids $/ \mu 1$ with $1.0 \mu \mathrm{g}$ of plasmid DNA $/ \mu 1$. The empty liposome $(50 \mathrm{nmol}$ of lipids $/ \mu 1$ ) contained no plasmid DNA.

The recombinant huIFN- $\beta$ protein (IFN- $\beta$ Mochida, $2.0 \times 10^{5} \mathrm{IU} / \mathrm{mg}$ ) was provided by Mochida Pharmaceutical Inc., Tokyo, Japan.

Anticancer drugs. Cisplatin (CDDP), adriamycin (ADR), 5-fluorouracil (5-FU), gemcitabine (GEM), paclitaxel (PTX) and irinotecan hydrochloride (CPT-11) were used in this experiment.

In vitro cytotoxicity assay. Cytotoxicity was evaluated by a colorimetric method using 2-(2-methoxy-4-nitrophenyl)-3(4-nitrophenyl)-5-(2,4-disulfophenyl)-2H-tetrazolium monosodium salt (WST-8, Nacalai Tesque, Kyoto, Japan) (18). Briefly, NC65 cells suspended in culture medium were placed in a 24-well plate at a density of $2.5 \times 10^{4}$ cells $/ \mathrm{ml}$ per well and cultured at $37^{\circ} \mathrm{C}$ in a humidified atmosphere of $5 \% \mathrm{CO}_{2}$ overnight. An aliquot of diluted IAB-1 suspension (from 0.001 to $0.10 \mu \mathrm{l} / \mathrm{ml}$ ), empty liposome suspension (from 0.001 to $0.10 \mu \mathrm{l} / \mathrm{ml}$ ), or huIFN- $\beta$ protein (from 100 to $10,000 \mathrm{IU} / \mathrm{mg}$ ) were added to each well, and then anticancer drugs were added. After $24 \mathrm{~h}$ of incubation, the medium was exchanged for $500 \mu \mathrm{l}$ of fresh medium and the cells were incubated for an additional $48 \mathrm{~h}$. The culture supernatant was replaced by $500 \mu \mathrm{l}$ of completely fresh medium containing $0.5 \mu \mathrm{mol}$ of tetrazolium salt. After incubation for $1 \mathrm{~h}$, the culture supernatant was harvested and absorbance (A) was measured at $450 \mathrm{~nm}$. Cytotoxicity was calculated as: cytotoxicity (\%) [1(absorbance of experimental wells/average absorbance of control wells)] x 100.

Animal care. We purchased female severe combined immunodeficiency (SCID) mice, 8-9 weeks of age from CLEA Japan (Osaka, Japan). The animals were fed irradiated mouse chow and autoclaved reverse osmosis-treated water. The Committee for Animal Research, Kyoto Prefectural University of Medicine, permitted this experimental procedure.

In vivo study. NC65 cells $\left(6 \times 10^{6}\right)$ were subcutaneously injected with a mixture of $50 \mu 1$ Matrigel (Becton-Dickinson, $\mathrm{NJ})$ and $50 \mu 1$ RPMI-1640 without antibiotics or serum into the right flanks of the SCID mice. Seven days after the tumor cell injection, the tumor had developed to 5-7 $\mathrm{mm}$ in length and $5 \mathrm{~mm}$ in width. Then, $30 \mu \mathrm{l}$ of IAB-1 (1.5 $\mu \mathrm{mol}$ of lipid with $30 \mu \mathrm{g}$ of plasmid DNA), $30 \mu \mathrm{l}$ of recombinant huIFN-B protein (6000 IU), $30 \mu 1$ of empty liposome (1.5 $\mu \mathrm{mol}$ of lipid), or $30 \mu 1$ of PBS were injected into the established tumors on days $0,2,7,9,14,16,21$ and 23 (twice a week for four courses). 5-FU $(800 \mu \mathrm{g})$ was injected into the peritoneal cavities on days 6, 13, 20 and 27 (once a week for four courses).

Tumor diameters were scaled with a digital caliper. The tumor volume was calculated as: volume $=a \mathrm{xb}^{2} / 2$, where $\mathrm{a}$, long diameter and $\mathrm{b}$, short diameter.

Measurement of thymidylate synthase (TS) activity. The activity of TS was determined by the 5-fluoro-2'-deoxyuridine 5'-monophosphate (FdUMP) binding assay combined with gel filtration as previously described in the References $(19,20)$. NC65 cells were sonicated in homogenized buffer (50 mM Tris- $\mathrm{HCl}, 1 \mathrm{mM}$ EDTA and $5 \mathrm{mM} \mathrm{MgCl}_{2} \mathrm{pH}$ 7.4) at maximum output (Sonifier cell disruptor 350: SmithKline), and centrifuged at $105,5000 \mathrm{~g}$ at $4^{\circ} \mathrm{C}$ for $60 \mathrm{~min}$ in a Beckman ultracentrifuge (model TL-100). The supernatant was divided into several tubes and frozen at $-80^{\circ} \mathrm{C}$ until use.

The supernatant was incubated with $\left[{ }^{3} \mathrm{H}\right]-$ FdUMP as well as $5,10-\mathrm{CH}_{2}-\mathrm{FH}_{4}$ at $30^{\circ} \mathrm{C}$ for $20 \mathrm{~min}$. The mixture was gelfiltered using a PD-10 column (Pharmacia Biotech, Uppsala, Sweden) to separate TS-bound from free $\left[{ }^{3} \mathrm{H}\right]$-FdUMP. The sample was eluted with PBS (-) and the total radioactivity of the fractions containing protein was measured. The protein content of the supernatant was measured using the BCA protein assay reagent (Pierce Chemical Co., Rockford, IL, USA).

Measurement of dihydropyrimidine dehydrogenase (DPD) activity. The NC65 cells were homogenized in 4 volumes of $50 \mathrm{mM}$ Tris- $\mathrm{HCl}$ (pH 8.0) containing $5 \mathrm{mM}$ 2-mercaptoethanol, $25 \mathrm{mM} \mathrm{KCl}$ and $5 \mathrm{mM} \mathrm{MgCl}_{2}$. The homogenate was centrifuged at $105,000 \mathrm{~g}$ for $1 \mathrm{~h}$ at $4^{\circ} \mathrm{C}$, and the supernatant fluid was used to measure the DPD activity (21). The assay mixture, in a final volume of $0.25 \mathrm{ml}$, consisted of $50 \mathrm{mM}$ Tris- $\mathrm{HCl}$ ( $\mathrm{pH} 8.0$ ), $10 \mathrm{mM} \mathrm{MgCl}_{2}, 25 \mathrm{mM} \mathrm{NaF}, 50 \mathrm{mM}$ nicotinamide, $5 \mathrm{mM}$ adenosine triphosphate (ATP), $1 \mathrm{mM}$ NHDPH, [6- $\left.{ }^{3} \mathrm{H}\right]$ 5-FU $(0.2 \mu \mathrm{Ci}$ and $20 \mu \mathrm{M})$ and the enzyme extract $(0.1 \mathrm{ml})$. The mixture was incubated for $30 \mathrm{~min}$ at $37^{\circ} \mathrm{C}$ and the reaction was stopped by heating at $100^{\circ} \mathrm{C}$ in a water bath. After centrifugation at $3000 \mathrm{rpm}$, the supernatant $(0.1 \mathrm{ml})$ was treated with $0.01 \mathrm{ml}$ of $2 \mathrm{M} \mathrm{KOH}$ for $30 \mathrm{~min}$ at room temperature. The mixture was treated with $0.005 \mathrm{ml}$ of 2 M PCA and centrifuged. An aliquot $(20 \mu \mathrm{l})$ of the supernatant was spotted onto a thin layer chromatography plate (Merck silica gel $60 \mathrm{~F} 254$ precoated plate, $2.5 \times 10 \mathrm{~cm}$, thickness $0.25 \mathrm{~mm}$ ) and developed with a mixture of chloroform, methanol and acetic acid $(17: 3: 1, \mathrm{v} / \mathrm{v} / \mathrm{v})$. The spots of 2-fluoro$ß$-alanine, 2-fluoro- $\beta$-ureidopropionic acid and 5-FU degradation products, were scraped into vials and mixed with $10 \mathrm{ml}$ of ACS-II scintillation fluid (Amersham, Buckinghamshire, UK). The radioactivity was measured in a Wallac 1410 liquid scintillation counter (Pharmacia, Uppsala, Sweden).

Measurement of orotate phosphoribosyltransferase (OPRT) activity. The NC65 cells were sonicated in homogenized 


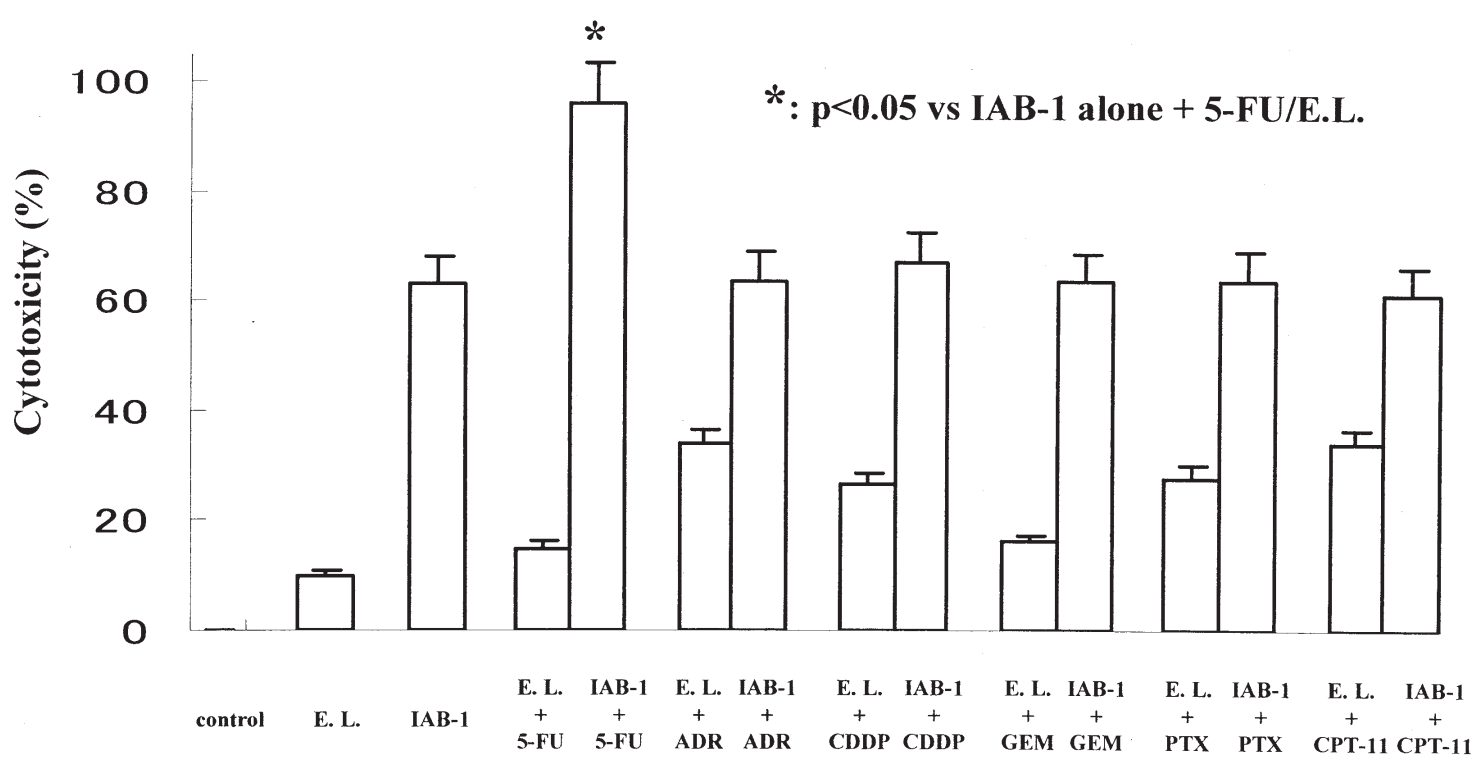

Figure 1. Cytotoxicity of IAB-1 in combination with anticancer drugs against NC65 cells in vitro. Cytotoxicity was evaluated by a colorimetric method using tetrazolium salt. NC65 cells placed in a 24-well plate at a density of $2.5 \times 10^{4}$ cells $/ \mathrm{ml}$ were cultured overnight at $37^{\circ} \mathrm{C}$. Medium (control), empty liposome (E.L.) $(0.10 \mu \mathrm{l} / \mathrm{ml})$, IAB-1 $(0.10 \mu \mathrm{l} / \mathrm{ml})$, CDDP $(1 \mu \mathrm{M})$, ADR $(0.01 \mu \mathrm{M}), 5$-FU $(10 \mu \mathrm{M})$, GEM $(0.1 \mu \mathrm{M})$, PTX $(0.05 \mu \mathrm{M})$, CPT-11 $(0.005 \mu \mathrm{M})$ and/or Taxol $(0.05 \mu \mathrm{M})$ were added. After incubation for $24 \mathrm{~h}$, the medium was exchanged for $500 \mu \mathrm{l}$ of fresh medium. After incubation for a further $48 \mathrm{~h}$, the cytotoxic effect was evaluated. Results derived from seven different experiments are expressed as means \pm SD. * $<<0.05$; IAB-1 alone versus IAB-1 + 5-FU/E.L.

buffer (50 mM Tris-HCl, $\mathrm{pH} 7.4$, and $5 \mathrm{mM}$ 2-mercaptoethanol) at maximum output using a Sonifier cell disruptor 350 (SmithKline, London, UK). They were centrifuged at $105,000 \mathrm{x}$ gravity at $4^{\circ} \mathrm{C}$ for $60 \mathrm{~min}$ in a model TL-100 (Beckman, Fullerton, CA) ultracentrifuge. The supernatants from each sample were divided into several tubes and frozen at $-80^{\circ} \mathrm{C}$ until use.

The test supernatant was incubated with $10 \mu \mathrm{M}\left[6-{ }^{3} \mathrm{H}\right]$ 5-FU (74 kBq), $50 \mathrm{mM}$ Tris- $\mathrm{HCl}, \mathrm{pH} 8.0,50 \mathrm{mM} \mathrm{MgCl}_{2}$, $10 \mathrm{mM} \mathrm{NaF}$ and $4 \mathrm{mM}$ phosphoribosylpyrophosphate at $37^{\circ} \mathrm{C}$ for $30 \mathrm{~min}$. Incubation was terminated by adding $2 \mathrm{M}$ perchloric acid, followed by centrifugation at $3000 \mathrm{rpm}$ for $10 \mathrm{~min}$. The supernatant $(100 \mu \mathrm{l})$ was then neutralized with $30 \mu 12 \mathrm{M} \mathrm{KOH}$ solution and $20 \mu 1$ aliquots were subjected to silica gel $60 \mathrm{~F}_{254}$ thin layer chromatography $(2.5 \times 10 \mathrm{~cm}$ and $0.25 \mathrm{~mm}$ thick) with a mixture of chloroform, methanol and acetic acid (17:3:1 volume per volume per volume) as the mobile phase. Spots of 5-fluorouridine 5'-monophosphate were scraped into vials and extracted with $0.1 \mathrm{ml} 4 \mathrm{M} \mathrm{HCl}$. The extracts were mixed with $10 \mathrm{ml}$ ACS-II (Amersham) scintillation fluid. Radioactivity was measured in a Wallac 1410 (Pharmacia) liquid scintillation counter. The protein content of the test supernatant was measured using the BCA protein assay reagent (Pierce Chemical Co.). OPRT activity was calculated per mg protein. Internal standards were used to compare assays. We analyzed the samples at the same time. This method made it possible to estimate OPRT activity $>0.05 \mathrm{pmol} / \mathrm{mg}$ protein per minute. Repeat measurements yielded almost the same results.

Measurement of thymidine phosphorylase (TP) activity by the thin layer chromatography method. The NC65 cells were homogenized in 4 volumes of $50 \mathrm{mM}$ Tris- $\mathrm{HCl}, \mathrm{pH} 8.0$, containing $5 \mathrm{mM}$ 2-mercaptoethanol, $25 \mathrm{mM} \mathrm{KCl}$ and $5 \mathrm{mM}$ $\mathrm{MgCl}_{2}$ and were centrifuged at $105,000 \mathrm{x} \mathrm{g}$ at $4^{\circ} \mathrm{C}$ for $60 \mathrm{~min}$ in an ultracentrifuge (Model TL-100; Beckman Instruments, Fullerton, CA). The supernatants from each sample were divided into several tubes and frozen at $-80^{\circ} \mathrm{C}$ until use.

The reaction mixture, in a total volume of $100 \mu 1$, consisted of $100 \mathrm{mM}$ sodium phosphate buffer, $\mathrm{pH} 6.4$; $\beta$-mercaptoethanol; $0.5 \mathrm{mM}\left[{ }^{3} \mathrm{H}\right]$ thymidine; and the supernatant $(50 \mu \mathrm{l})$. The mixture was incubated for $20 \mathrm{~min}$ at $37^{\circ} \mathrm{C}$, and the reaction was stopped by heating at $100^{\circ} \mathrm{C}$ in a water bath. After centrifugation at $14,000 \mathrm{rpm}$ for $2 \mathrm{~min}$, the supernatant $(20 \mu 1)$ was applied to a polyethylenemine cellulose TLS sheet and was developed with distilled water. The spots corresponding to the substrate and product were visualized under ultraviolet light and excised, and the level of radioactivity in each was measured. Internal standards were used to compare assays. This method made it possible to estimate TP activity $>0.01 \mathrm{nmol} / \mathrm{mg}$ protein per minute. We analyzed the samples at the same time.

\section{Results}

In vitro treatment with IAB-1 in combination with anticancer drugs against NC65 cells. Treatment with IAB-1 at $0.1 \mu \mathrm{l} / \mathrm{ml}$ against the NC65 cells resulted in strong cytotoxicity, compared with the $1000 \mathrm{IU} / \mathrm{ml}$ recombinant huIFN-B protein (data not shown). We used CDDP, ADR, 5-FU, GEM, PTX and CPT-11 as anticancer agents for combination therapy. The cytotoxicity induced by IAB-1 in combination with CDDP, ADR, GEM, PTX or CPT-11 was almost the same as that induced by IAB-1 alone. However, treatment with IAB-1 and 5-FU resulted in significant anticancer activity, compared with IAB-1 alone (Fig. 1). Similar results were observed, when IAB-1 and 5-FU were used at different concentrations (Fig. 2). These results suggest that the combination treatment of NC65 cells with IAB-1 and 5-FU demonstrates synergistic cytotoxicity. 


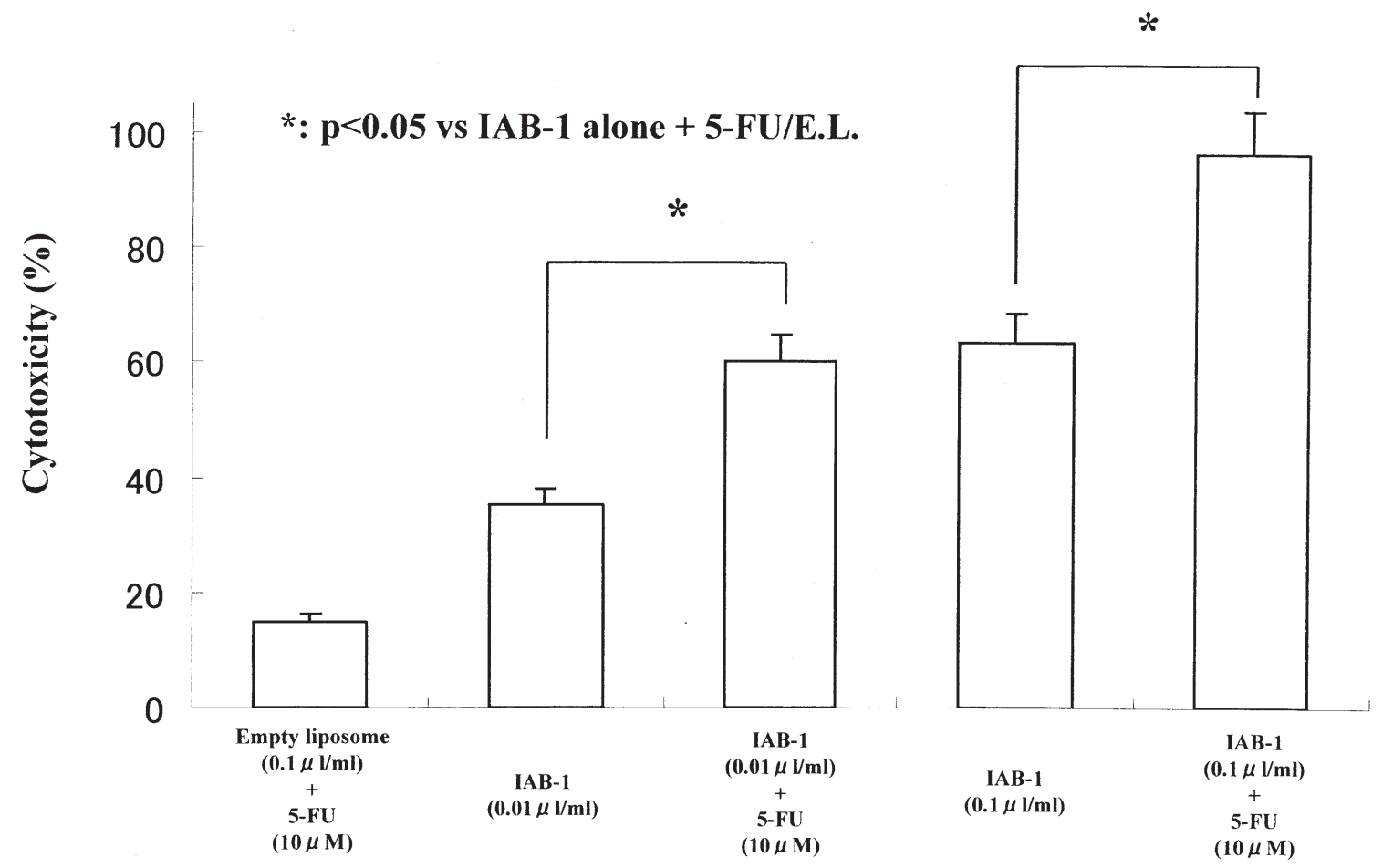

Figure 2. Cytotoxicity of IAB-1 in combination with 5-FU against NC65 cells in vitro. NC65 cells were treated with empty liposome (0.10 $\mu 1 /$ ml), IAB-1 $(0.01 \mu \mathrm{l} / \mathrm{ml})$, IAB-1 $(0.10 \mu \mathrm{l} / \mathrm{ml})$ and/or 5-FU $(10 \mu \mathrm{M})$ for $24 \mathrm{~h}$. The medium was aspirated and the NC65 cells were washed with RPMI-1640 medium. Cytotoxicity was assessed by a two-day assay. ${ }^{*} \mathrm{p}<0.05$; IAB-1 alone versus IAB-1 + 5-FU/E.L.

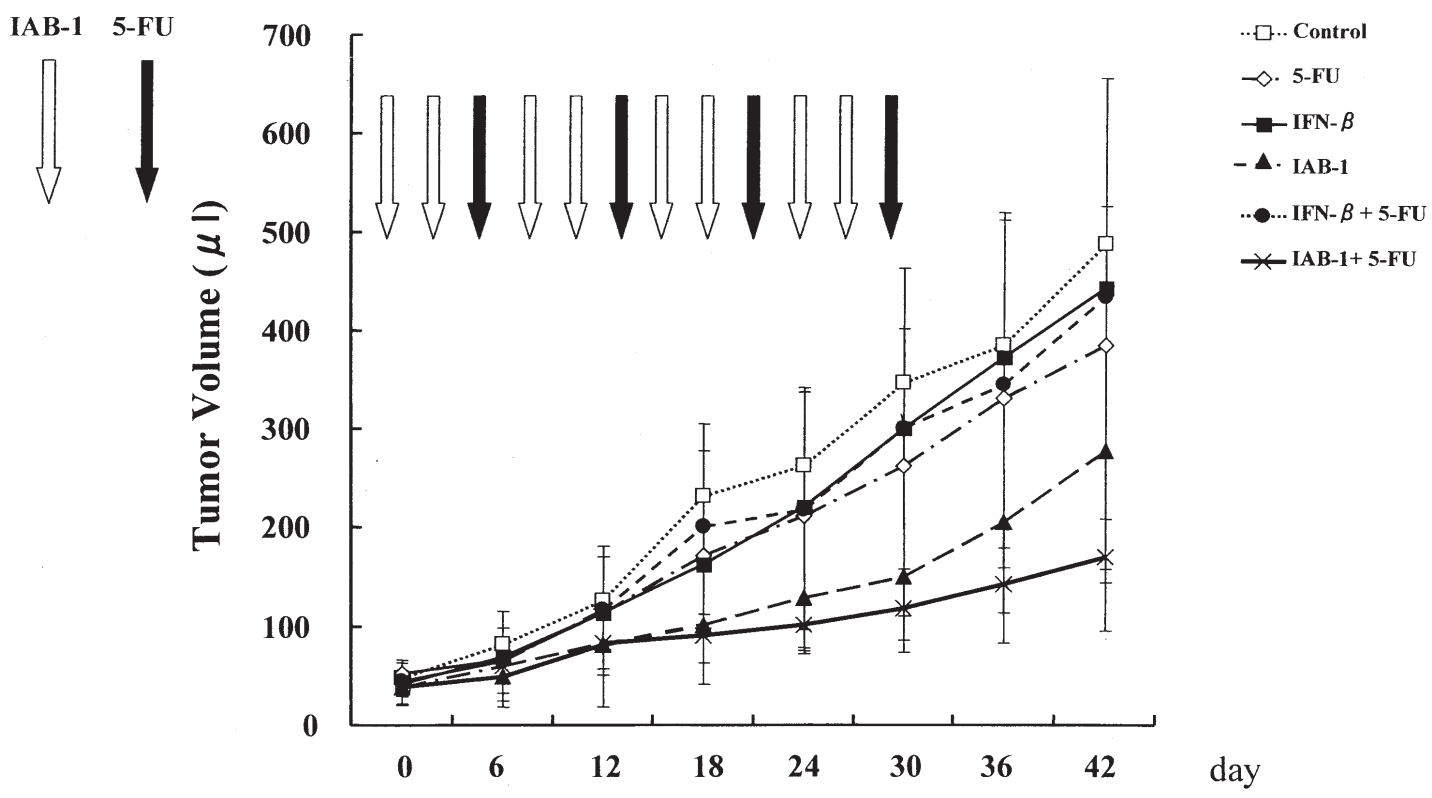

Figure 3. In vivo treatment with IAB-1 in combination with 5-FU against NC65 tumors. Seven days before the first treatment, 6 million NC65 cells were subcutaneously injected into the right flank of SCID mice. Then, $30 \mu 1$ of IAB-1 (1.5 $\mu$ mol of lipid with $30 \mu \mathrm{g}$ of plasmid DNA), $30 \mu 1$ of recombinant huIFN- 3 protein (6000 IU), $30 \mu \mathrm{l}$ of empty liposome (1.5 $\mu \mathrm{mol}$ of lipid), or $30 \mu 1$ of PBS (control) were injected into established tumors on days $0,2,7,9,14,16,21$ and 23 (twice a week for four courses). 5-FU $(800 \mu \mathrm{g}$ ) was injected into the peritoneal cavities on days 6, 13, 20 and 27 (once a week for four courses). The tumor volume growth curves are shown. $\mathrm{p}<0.05$; IAB- 1 versus control, 5-FU, and IFN- $\beta$ and $\mathrm{p}<0.05$; IAB- $1+5$-FU versus control, 5-FU, IFN- $\beta$ and IFN- $\beta+5$-FU.

Effect of the treatment sequence with IAB-1 and 5-FU on synergistic cytotoxicity. The simultaneous treatment of NC65 cells with IAB-1 and 5-FU resulted in synergistic cytotoxicity. The effect of sequential treatment with IAB-1 and 5-FU was compared with the treatment of the two agents together. NC65 cells were treated for $24 \mathrm{~h}$ with one agent, the medium was exchanged, the second agent was added for $24 \mathrm{~h}$ and the cells were tested for viability. The results show that synergy was obtained irrespective of the treatment sequence (data not shown). Similar results were observed when IAB-1 and 5-FU 


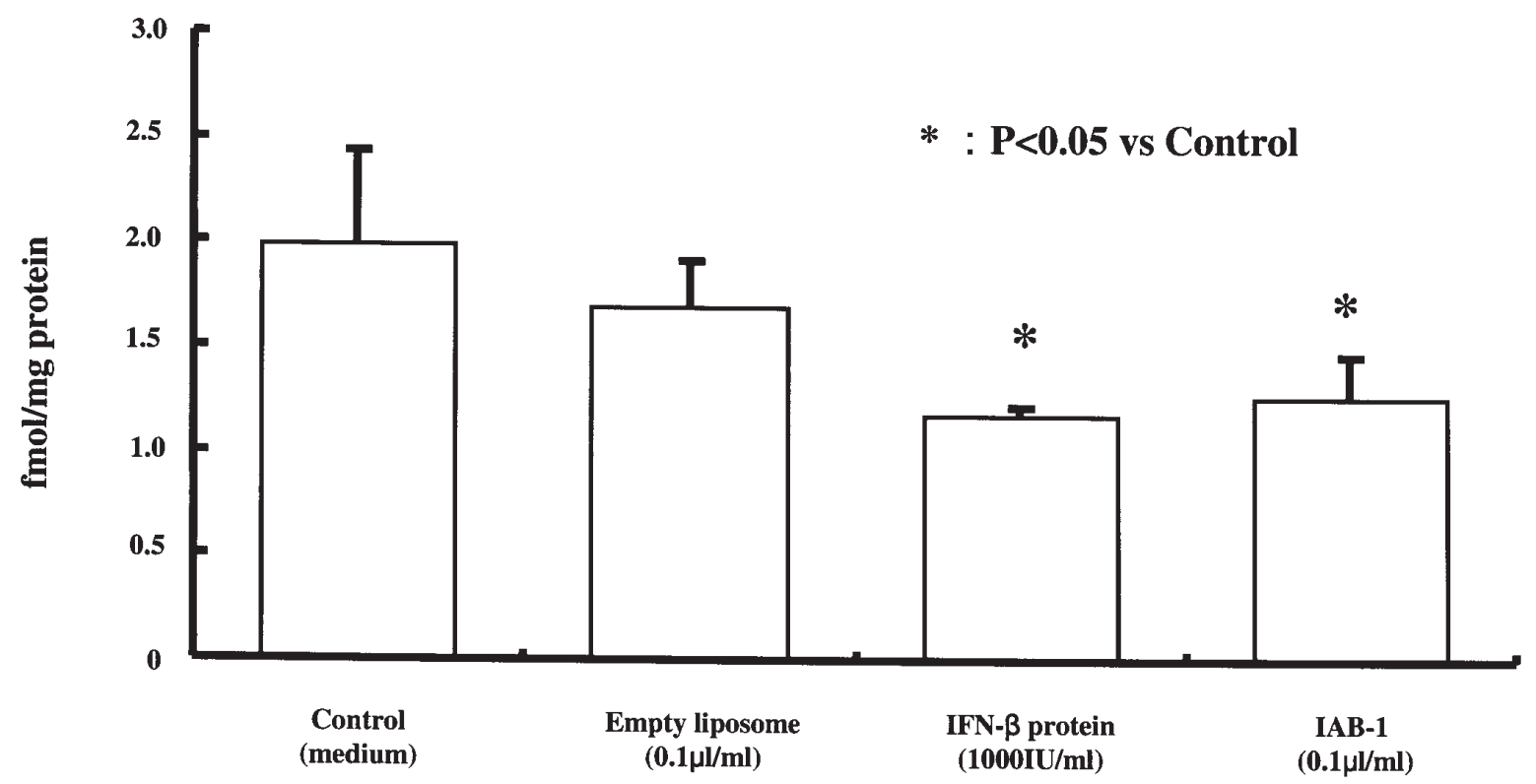

Figure 4. Suppressed TS activity in NC65 cells by IAB-1. TS activity was examined by the FdUMP binding assay. TS activity in the NC65 cells was decreased by IAB-1 or IFN-ß protein.

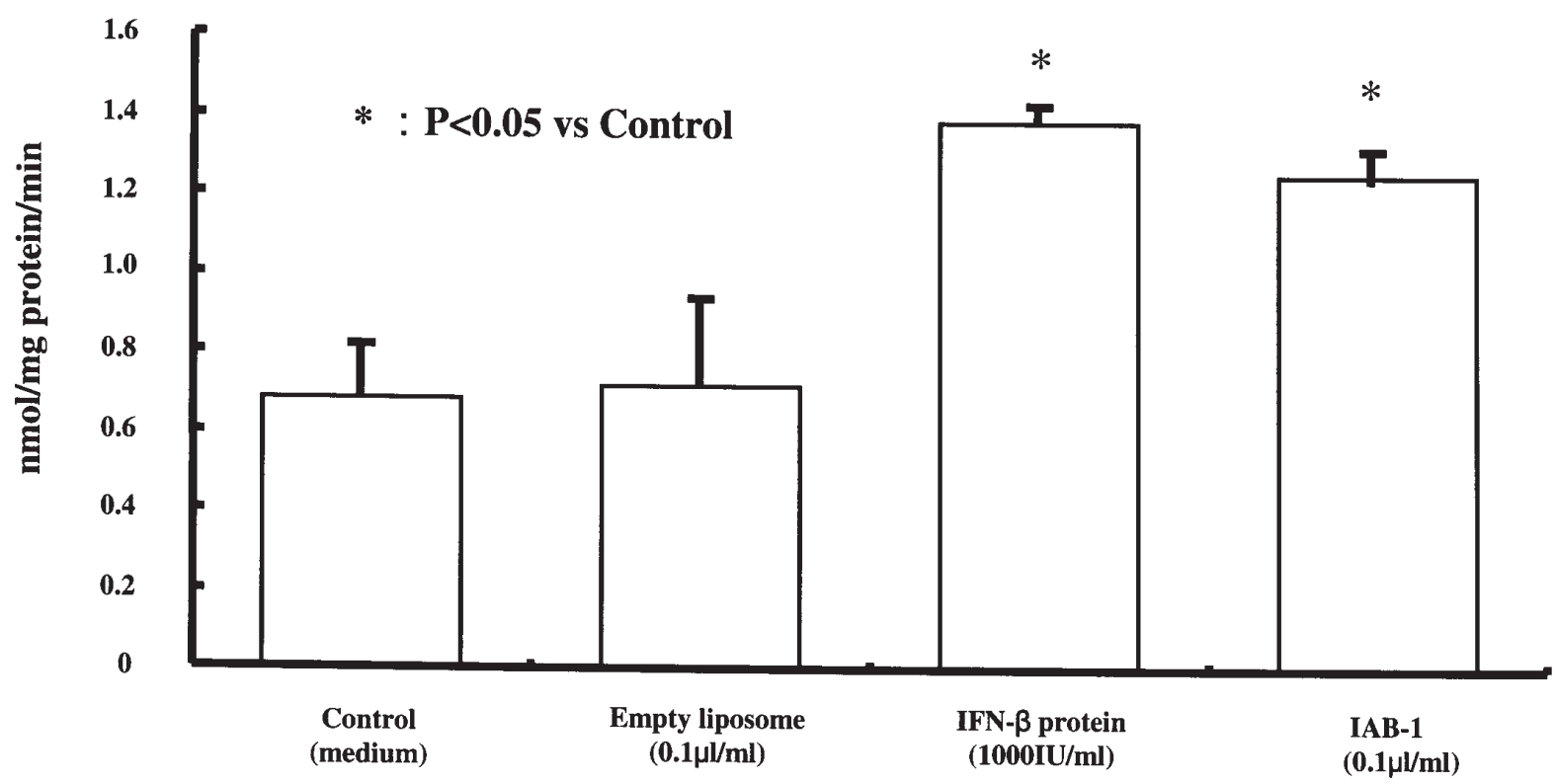

Figure 5. Enhanced TP activity in NC65 cells by IAB-1. TP activity was measured by a thin layer chromatography assay. TP activity in the NC65 cells was enhanced by IAB-1 or IFN- $\beta$ protein.

were used at different concentrations. These findings show that the sequence of treatment with IAB-1 and 5-FU is not critical for obtaining maximal cytotoxicity in RCC cells.

In vivo treatment with IAB-1 in combination with 5-FU against NC65 cells. We examined the antitumor effect of IAB-1 in combination with 5-FU in vivo. The NC65 tumors transfected with IAB-1 in mice were significantly smaller than those receiving an injection of empty liposome or the recombinant huIFN- $\beta$ protein (Fig. 3). Similar to the result in vitro, treatment with IAB-1 in combination with 5-FU resulted in significant anticancer activity, compared with IAB-1 alone.

Effects of IAB-1 on TS, DPD, OPRT and TP activities in NC65 cells. The properties of important enzymes in the metabolic pathways of 5-FU, TS, DPD, OPRT and TP in the cell lysate treated with IAB-1 were measured. TS is a target enzyme of 5-FU, while IAB-1 down-regulated TS activity (Fig. 4). DPD is the rate-limiting enzyme in the pathway of 
5-FU catabolism, while IAB-1 had no effect on DPD activity (data not shown). OPRT and TP convert 5-FU to the active metabolite, FdUMP. Although IAB-1 had no effect on OPRT activity, IAB-1 up-regulated TP activity (Fig. 5). These results suggest that IAB-1 enhances 5-FU cytotoxicity by downregulating TS activity and up-regulating TP activity.

\section{Discussion}

RCC accounts for $2 \%$ of all cancer cases worldwide. Metastatic disease is often present at the time of diagnosis of RCC, and its poor response to chemotherapy and radiotherapy determines its poor prognosis. Cytokines, IFN- $\alpha,-\beta,-\gamma$ and IL-2 are used for patients with RCC. However, the response rate is $\sim 15 \%$. We have reported that significant and continuous huIFN- $B$ production was detected in the culture medium of NC65 cells after transfection with IAB-1 (10). Apoptosis was observed in cells treated with IAB-1, but the recombinant huIFN- $\beta$ protein failed to induce apoptosis. IAB- 1 and the recombinant huIFN- $\beta$ protein may have different mechanisms concerning antitumor effects.

As treatment for metastatic RCC, combination therapy with cytokines, IFN, IL-2 and anticancer drugs, 5-FU and GEM is used. Some investigators have reported that the combination therapy was more effective than cytokine therapy alone (23-27). Experimental studies have demonstrated some evidence of synergism between chemotherapeutic agents, notably 5-FU and recombinant IFN- $\alpha$ (28). However, the addition of 5-FU to recombinant IFN- $\alpha$ does not have sufficient antitumor activity against metastatic RCC. The combination of IFN- $\beta$ gene therapy and 5-FU resulted in a significant tumor regression in esophageal and colorectal cancer cells $(29,30)$. We examined the antitumor effect of IAB-1 and anticancer agents including 5-FU.

CDDP, ADR, GEM, PTX and CPT-11 did not enhance IAB-1 cytotoxicity against RCC. Combination therapy with IAB-1 and 5-FU was more cytotoxic than IAB-1 alone. These results suggest that combination therapy with IAB-1 and 5-FU is more beneficial for the treatment against RCC.

We then examined the mechanisms responsible for the significant antitumor activity of IAB-1 and 5-FU against RCC. 5-FU is a prodrug that is converted by several enzymes including OPRT and TP to the active metabolite, FdUMP, which binds to TS and inhibits DNA synthesis. 5-FU is catabolized mainly by DPD. This study demonstrated that IAB-1 enhanced TP but suppressed TS activity. Therefore, IAB-1 may augment 5-FU cytotoxicity by these effects.

In vivo, tumors transfected with $\mathrm{IAB}-1$ and $5-\mathrm{FU}$ in mice were smaller than those treated by IAB-1 alone. In addition, the body weight of mice treated with IAB-1 and 5-FU as controls did not change during the treatments (data not shown). Therefore, it may be safe to use combination therapy with IAB-1 and 5-FU clinically.

The overall response rate of patients with RCC to immunotherapy and molecular-targeted therapy has gradually improved. However, drug resistance and metastatic RCC remain important issues and more effective therapies are necessary for these patients. The current study demonstrates that combination treatment with IAB-1 and 5-FU resulted in enhanced cytotoxicity in RCC cells. These findings suggest that combination treatment with IAB-1 and 5-FU is useful in patients with RCC as a new form of therapy with more selective cytotoxicity and less collateral toxicity.

\section{Acknowledgements}

We would like to thank Professor Benjamin Bonavida (UCLA, Los Angeles, CA, USA) for his helpful input. Yukako Morioka provided laboratory technical assistance.

\section{References}

1. Miyake H, Hara I, Sakai I, et al: Clinical outcome of combined immunotherapy with low-dose interleukin-2 and interferonalpha for Japanese patients with metastatic renal cell carcinoma who had undergone radical nephrectomy: a preliminary report. Int J Clin Oncol 10: 338-341, 2005.

2. Alatrash G, Hutson TE, Molto L, et al: Clinical and immunologic effects of subcutaneously administered interleukin-12 and interferon alfa-2b: phase I trial of patients with metastatic renal cell carcinoma or malignant melanoma. J Clin Oncol 22: 2891-2900, 2004.

3. Rinehart JJ, Young D, Laforge J, Colburn D and Neidhart J: Phase I/II trial of recombinant gamma-interferon in patients with renal cell carcinoma: immunologic and biologic effects. J Biol Response Mod 6: 302-312, 1987 .

4. Atzpodien J, Kirchner H, Illiger HJ, et al: IL-2 in combination with IFN-alpha and 5-FU versus tamoxifen in metastatic renal cell carcinoma: long-term results of a controlled randomized clinical trial. Br J Cancer 85: 1130-1136, 2001

5. Dutcher JP, Logan T, Gordon M, et al: Phase II trial of interleukin 2, interferon alpha, and 5-fluorouracil in metastatic renal cell cancer: a cytokine working group study. Clin Cancer Res 6: 3442-3450, 2000.

6. Kawai K, Tani K, Yamashita N, et al: Advanced renal cell carcinoma treated with granulocyte-macrophage colonystimulating factor gene therapy: a clinical course of the first Japanese experience. Int J Urol 9: 462-466, 2002.

7. Berns AJ, Clift S, Cohen LK, et al: Phase I study of nonreplicating autologous tumor cell injections using cells prepared with or without GM-CSF gene transduction in patients with metastatic renal cell carcinoma. Hum Gene Ther 6: 347-368, 1995.

8. Schmidt-Wolf IG, Finke S, Trojaneck B, et al: Phase I clinical study applying autologous immunological effector cells transfected with the interleukin-2 gene in patients with metastatic renal cancer, colorectal cancer and lymphoma. Br J Cancer 81: 1009-1016, 1999.

9. Galanis E, Hersh EM, Stopeck AT, et al: Immunotherapy of advanced malignancy by direct gene transfer of an interleukin-2 DNA/DMRIE/DOPE lipid complex: phase I/II experience. J Clin Oncol 17: 3313-3323, 1999.

10. Nakanishi H, Mizutani Y, Kawauchi A, et al: Significant antitumoral activity of cationic multilamellar liposomes containing human IFN-beta gene against human renal cell carcinoma. Clin Cancer Res 9: 1129-1135, 2003.

11. Matsubara H, Mizutani Y, Hongo F, et al: Gene therapy with TRAIL against renal cell carcinoma. Mol Cancer Ther 5: 2165-2171, 2006.

12. Natsume A, Tsujimura K, Mizuno M, Takahashi T and Yoshida J: IFN-beta gene therapy induces systemic antitumor immunity against malignant glioma. J Neurooncol 47: 117-124, 2000.

13. Aoki H, Mizuno M, Natsume A, et al: Dendritic cells pulsed with tumor extract-cationic liposome complex increase the induction of cytotoxic T lymphocytes in mouse brain tumor. Cancer Immunol Immunother 50: 463-468, 2001.

14. Tana, Watarai S, Lee JT, et al: In vivo antitumor effect of cationic liposomes containing diphtheria toxin A-chain gene on cells infected with bovine leukemia virus. J Vet Med Sci 59: 617-619, 1997.

15. Zhao DD, Watarai S, Lee JT, Kouchi S, Ohmori H and Yasuda T: Gene transfection by cationic liposomes: comparison of the transfection efficiency of liposomes prepared from various positively charged lipids. Acta Med Okayama 51: 149-154, 1997.

16. Arima H, Aramaki Y and Tsuchiya S: Effects of oligodeoxynucleotides on the physicochemical characteristics and cellular uptake of liposomes. J Pharm Sci 86: 438-442, 1997. 
17. Lee JT, Watarai S, Kakidani H, Onuma M, Zhao DD and Yasuda T: Evaluation of cationic liposomes for delivery of diphtheria toxin A-chain gene to cells infected with bovine leukemia virus. J Vet Med Sci 59: 169-174, 1997.

18. Matsuoka M, Wispriyono B and Igisu H: Increased cytotoxicity of cadmium in fibroblasts lacking c-fos. Biochem Pharmacol 59: $1573-1576,2000$

19. Foekens JA, Romain S, Look MP, Martin PM and Klijn JG: Thymidine kinase and thymidylate synthase in advanced breast cancer: response to tamoxifen and chemotherapy. Cancer Res 61: 1421-1425, 2001

20. Spears CP, Shahinian AH, Moran RG, Heidelberger C and Corbett TH: In vivo kinetics of thymidylate synthetase inhibition of 5-fluorouracil-sensitive and -resistant murine colon adenocarcinomas. Cancer Res 42: 450-456, 1982.

21. Mizutani Y, Wada H, Ogawa O, et al: Prognostic significance of thymidylate synthase activity in bladder carcinoma. Cancer 92: 510-518, 2001.

22. Mizutani Y, Wada H, Yoshida O, Fukushima M, Nakanishi H and Miki T: Significance of orotate phosphoribosyltransferase activity in renal cell carcinoma. J Urol 171: 605-610, 2004.

23. Massacesi C, Burattini L, Marcucci F and Bonsignori M: Short communication: the efficacy of fixed dose rate infusion of gemcitabine combined with IFN-alpha2a in patients with advanced refractory renal cell carcinoma. J Interferon Cytokine Res 25: 165-168, 2005.

24. Samland D, Steinbach F, Reiher F, Schmidt U, Gruss A and Allhoff EP: Results of immunochemotherapy with interleukin-2, interferon-alpha2 and 5-fluorouracil in the treatment of metastatic renal cell cancer. Eur Urol 35: 204-209, 1999.
25. Atzpodien J, Kirchner H, Hanninen EL, Deckert M, Fenner M and Poliwoda H: Interleukin-2 in combination with interferonalpha and 5-fluorouracil for metastatic renal cell cancer. Eur $\mathbf{J}$ Cancer 29A: S6-S8, 1993.

26. Lopez Hanninen E, Kirchner H and Atzpodien J: Interleukin-2 based home therapy of metastatic renal cell carcinoma: risks and benefits in 215 consecutive single institution patients. J Urol 155: $19-25,1996$.

27. Atzpodien J, Kirchner H, Duensing S, et al: Biochemotherapy of advanced metastatic renal-cell carcinoma: results of the combination of interleukin-2, alpha-interferon, 5-fluorouracil, vinblastine, and 13-cis-retinoic acid. World J Urol 13: 174-177, 1995.

28. Kase S, Kubota T, Watanabe M, Teramoto T, Kitajima M and Hoffman RM: Recombinant human interferon alpha-2a increases 5-fluorouracil efficacy by elevating fluorouridine concentration in tumor tissue. Anticancer Res 14: 1155-1159, 1994.

29. Tsunoo H, Komura S, Ohishi N, et al: Effect of transfection with human interferon-beta gene entrapped in cationic multilamellar liposomes in combination with 5-fluorouracil on the growth of human esophageal cancer cells in vitro. Anticancer Res 22: 1537-1543, 2002

30. Choi EA, Lei H, Maron DJ, et al: Combined 5-fluorouracil/ systemic interferon-beta gene therapy results in long-term survival in mice with established colorectal liver metastases. Clin Cancer Res 10: 1535-1544, 2004. 